\title{
Penentuan Strategi Promosi Usaha Mikro Kecil Dan Menengah (UMKM) Menggunakan Metode CRISP-DM dengan Algoritma K-Means Clustering
}

\author{
Dwi Astuti ${ }^{\# 1}$, Ade Rahmat Iskandar ${ }^{* 2}$, Atik Febrianti ${ }^{\# 3}$ \\ \# Institut Teknologi Telkom Purwokerto \\ Jl. D.I. Panjaitan 128, Purwokerto, Indonesia \\ ${ }^{1}$ 15102094@ittelkom-pwt.ac.id \\ ${ }^{2}$ Ade.rahmat@ittelkom-pwt.ac.id \\ 3 atik@ittelkom-pwt.ac.id
}

Accepted on April 11, 2019

\begin{abstract}
Terjadinya penurunan jumlah UMKM sebesar 0,003\% menyebabkan pertumbuhan ekonomi lesu pada kuartal II di Indonesia. Adanya sumber data UMKM yang melimpah disebuah daerah dapat digunakan untuk menggali informasi. Pengelompokan data UMKM yang memanfaatkan proses data mining dengan menggunakan teknik clustering dapat digunakan untuk mengolah data yang ada. Pada prosesnya, metode yang digunakan adalah pemahaman bisnis, pemahaman data, persiapan data, pemodelan, evaluasi dan persebaran. Dalam pembentukan cluster, algoritma yang digunakan adalah $K$-Means. K-means clustering merupakan salah satu algoritma yang dapat mengelompokkan data kedalam beberapa cluster berdasarkan kemiripan data. Sehingga UMKM yang memiliki karakteristik sama akan dimasukkan ke dalam satu cluster dan data dengan karakteristik yang berbeda akan dikelompokkan ke dalam cluster lainnya. Dalam prosesnya, penelitian ini akan menguji data berupa jenis usaha, aset dan omset. Data UMKM akan diolah menggunakan python guna untuk menghasilkan cluster yang akurat. Cluster yang terbentuk dari proses clustering ini ada 3 (tiga) cluster dengan cluster satu sebanyak 182 UMKM, cluster dua terdiri dari 47 UMKM, dan cluster tiga terdiri dari 55 UMKM. Penelitian ini diharapkan mengeluarkan output berupa klusterisasi atau pengelompokkan data yang sesuai untuk dasar pengambilan keputusan dalam penentuan strategi promosi. Sehingga dapat menghasilkan informasi yang akurat bagi UMKM untuk membantu mengembangkan usahanya.
\end{abstract}

Keywords: UMKM, Data Mining, Clustering, CRISP-DM, K-Means

\section{PENDAHULUAN}

$\mathbf{U}$ MKM memiliki peran yang sangat penting bagi perkembangan perekonomian Indonesia. Karena pasca krisis ekonomi 1998 UMKM menyumbang Produk Domestik Bruto (PDB) nasional sekitar 60,34\% dan memiliki proporsi unit usaha sebesar 99,99\% dari total keseluruhan pelaku usaha di Indonesia[1]. Namun demikian, berdasarkan data Kementrian Koperasi dan UKM tahun 2016 yang didapat dari Badan Pusat Statistik (BPS) pada Tabel 1.1 menunjukkan bahwa selama tahun 2008-2013 persentase pertumbuhan 
jumlah UMKM mengalami fluktuasi yang berujung pada penurunan sekitar 0,003\% di tahun 2013[2]. Penurunan ini pun terjadi di salah satu wilayah Purwokerto Selatan. Berdasarkan data yang diperoleh dari Kelurahan Purwokerto Selatan, Jumlah UMKM pada tahun 2016 ada 197 unit usaha dan di tahun 2017 turun menjadi 167 unit usaha UMKM. Jadi, terdapat penurunan sejumlah 30 usaha pada tahun 2017[3]. Direktur Eksekutif Institute for Economic (Indef) Enny Sri Hartati menilai goyahnya sektor UMKM menyebabkan pertumbuhan ekonomi yang lesu pada kuartal II. Hal ini tentunya berdampak pada pertumbuhan ekonomi negara. Menurut LPPI dan Bank Indonesia, ada banyak kendala penyebab penurunan presentase jumlah UMKM. Salah satu faktor kendala pertumbuhan UMKM yaitu masih belum adanya strategi pemasaran yang tepat bagi para pelaku UMKM untuk memasarkan produknya[1]. Hal ini dapat dijadikan studi bagi peneliti.

Tabel 1.1 Pertumbuhan Jumlah UMKM 2008-2013[2]

\begin{tabular}{|c|c|c|}
\hline No & Tahun & Pertumbuhan Jumlah UMKM (Persen) \\
\hline 1 & 2008 & 2,520 \\
\hline 2 & 2009 & 2,640 \\
\hline 3 & 2010 & 2,010 \\
\hline 4 & 2011 & 2,570 \\
\hline 5 & 2012 & 2,410 \\
\hline 6 & 2013 & 2,407 \\
\hline
\end{tabular}

(Sumber Data : Badan Pusat Statistik Nasional (BPS) 2016)

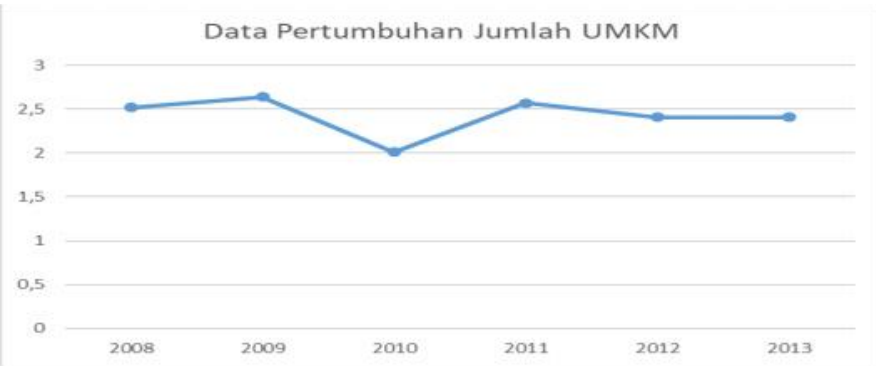

Grafik 1.1 Pertumbuhan Jumlah UMKM Tahun 2008 - 2013[2]

(Sumber Data : Badan Pusat Statistik Nasional (BPS) 2016)

Kemajuan teknologi informasi saat ini sudah semakin berkembang. Dengan berkembangnya teknologi, kumpulan data UMKM yang melimpah di suatu daerah dapat diolah menggunakan suatu metode. Metode yang tepat untuk melakukan tahap penelitian ini adalah Data Mining. Data mining merupakan rangkaian proses yang mengolah sekumpulan data yang berlimpah untuk menggali informasi yang belum diketahui dengan mengenali pola-pola dari suatu data[4]. Tujuan pengenalan pola ini adalah memanipulasi suatu data untuk mendapatkan informasi yang berharga. Informasi ini dapat digunakan sebagai solusi bisnis bagi UMKM khususnya didalam penentuan strategi promosi.

Salah satu metode yang ada didalam Data Mining adalah metode Clustering. Clustering bekerja dengan cara mengumpulkan data kedalam satu kelompok data yang memiliki karakteristik yang sama kedalam beberapa objek atau variabel tertentu hingga menemukan pola-pola yang diinginkan[5]. Algoritma yang tepat untuk menemukan pola-pola tersembunyi dari data ini adalah K-Means. Algoritma K-Means merupakan metode yang mempartisi data kedalam bentuk satu atau lebih cluster yang memiliki karakteristik sama. Metode ini memiliki akurasi atau tingkat ketelitian yang tinggi, waktu eksekusi yang relatif cepat (tergantung jumlah data yang diolah) karena sifatnya yang linear, dan sudah umum digunakan sehingga mudah untuk diadaptasi [6].

Berdasarkan persoalan di atas, studi ini spesifik meneliti tentang algoritma $K$-Means Clustering yang dapat digunakan sebagai salah satu cara untuk menenentukan strategi promosi yang tepat bagi UMKM dalam persaingan bisnis global. Pada algoritma ini data akan dibagi menjadi 3 variabel yang akan dikelompokan kedalam cluster tertentu sesuai dengan karakteristiknya.

Studi literatur yang sudah ada, dapat dijadikan landasan untuk melaksanakan penelitian ini. Studi ini akan dilakukan di wilayah Purwokerto. Penelitian ini diharapkan dapat dijadikan referensi bagi pemerintah 
khususnya UMKM dalam menentukan strategi promosi yang tepat guna menunjang produktivitas UMKM yang akan berimbas pada peningkatan kesejahteraan ekonomi nasional.

\section{KAJIAN TERKAIT}

Penelitian Aulia Tegar Rahman, Wiranto dan Rini Anggrainingsih yang berjudul "Coal Trade Data Clustering Using K-Means" membahas tentang strategi untuk meningkatkan perdagangan produk melalui analisis data penjualan. Salah satu metode Data Mining yang digunakan untuk menentukan pola penggalian informasi adalah Clustering dengan proses penentuan pola pengelompokan menggunakan K-Means. Penelitian ini menghasilkan 8 cluster menggunakan metode Elbow. Ada persamaan karakteristik di setiap cluster. Cluster optimal digunakan sebagai penentuan srategi bisnis[6].

Penelitian Johan Oscar Ong yang berjudul "Implementasi Algoritma K-Means Clustering Untuk Menentukan Strategi Marketing President University" membahas mengenai pengolahan data mahasiswa yang telah lulus. Data diolah menggunakan algoritma K-Means Clustering yaitu dengan mengelompokkan data mahasiswa kedalam beberapa cluster berdasarkan karakteristik data yang digunakan untuk memperoleh informasi tersembunyi. Atribut yang digunakan dalam penelitian ini sudah ditentukan yaitu nama, kota asal, jurusan dan IPK mahasiswa. Informasi yang diperoleh dari penelitian ini dapat digunakan sebagai referensi dalam menentukan strategi pemasaran yang tepat bagi departemen pemasaran President University[7].

Penelitian Elly Murningsih dan Sri Kiswati yang berjudul "Penerapan Metode K-Means untuk Clustering Produk Online Shop Dalam Penentuan Stok Barang" membahas tentang manajemen stok yang dilakukan secara tidak akurat menyebabkan biaya simpan yang tinggi dan tidak ekonomis. Hal ini disebabkan karena terjadinya kekosongan dan kelebihan produk tertentu. Penelitian ini menggunakan metode clustering untuk mengetahui produk mana yang paling diminati oleh konsumen. Variabel yang digunakan adalah kode produk, jumlah transaksi, volume penjualan dan rata-rata penjualan. Hasil akhir dari penelitian ini berupa suatu program aplikasi yang dapat digunakan untuk mengelompokkan produk menjadi kategori jumlah stok banyak, sedang dan sedikit berdasarkan transaksi penjualan[8].

Penelitian Annisa Paramitha Fadillah yang berjudul "Penerapan Metode CRISP-DM untuk Prediksi Kelulusan Studi Mahasiswa Menempuh Mata Kuliah (Studi Kasus Universitas XYZ)" membahas tentang penggunaan metode CRISP-DM sebagai proses standar penambangan data yang dapat diterapkan pada strategi pemecahan masalah bisnis. Algoritma yang digunakan adalah C4.5 desicion tree. Hasil penelitian ini adalah prediksi pola kelulusan siswa[9].

Penelitian Beta Esti Adiana, Indah Soesanti, dan Adhistya Erna Permanasari dengan judul "Analisis Segmentasi Pelanggan Menggunakan Kombinasi RFM Model dan Teknik Clustering" membahas tentang segmentasi pelanggan yang dilakukan dengan pendekatan data mining dengan metode Clustering dengan tujuan untuk mengukur kesetiaan pelanggan terhadap sebuah produk UKM. Dengan menggunakan CRISPDM yang terdiri dari enam fase yaitu fase pemahaman bisnis, fase pemahaman data, fase persiapan data, fase pemodelan, fase evaluasi dan fase penerapan. Pembentukan klaster didasarkan pada analisa RFM (Recency, Frequency, and Monetary). Davies Bouldin Index (DBI) digunakan untuk menemukan jumlah cluster (k) yang optimal. Hasil dari penelitian ini terbentuk 3 kelompok pelanggan. Kelompok pertama berjumlah 30 pelanggan yang masuk kedalam kategori typical customer, 8 pelanggan masuk dalam kategori superstar, dan 89 pelanggan masuk pada kategori dormant customer[10].

Berdasarkan penelitian diatas, dapat diambil kesimpulan bahwa algoritma K-Means sangat baik digunakan untuk menyelesaikan masalah tentang pengolahan data berdasarkan cluster. Pengelompokkan atau clusterisasi di sebuah UMKM menawarkan beberapa kekurangan dan kelebihan. Belum adanya data UMKM yang telah dikelompokkan dan belum adanya kategori strategi promosi yang handal menjadikan tantangan tersendiri dalam penulisan ini dengan menggunakan metode CRISP-DM melalui tahapan business understanding, data understanding, data preparation, modeling, evaluasi dan development untuk membuat penelitian ini lebih terarah. 


\section{RESEARCH METHOD}

Penelitian ini menggunakan 284 data UMKM di sektor industri pengolahan Purwokerto dengan menerapkan metode CRISP-DM dan algoritma K-Means clustering untuk menentukan strategi promosi UMKM. Tahapan-tahapan yang akan dilakukan adalah sebagai berikut:

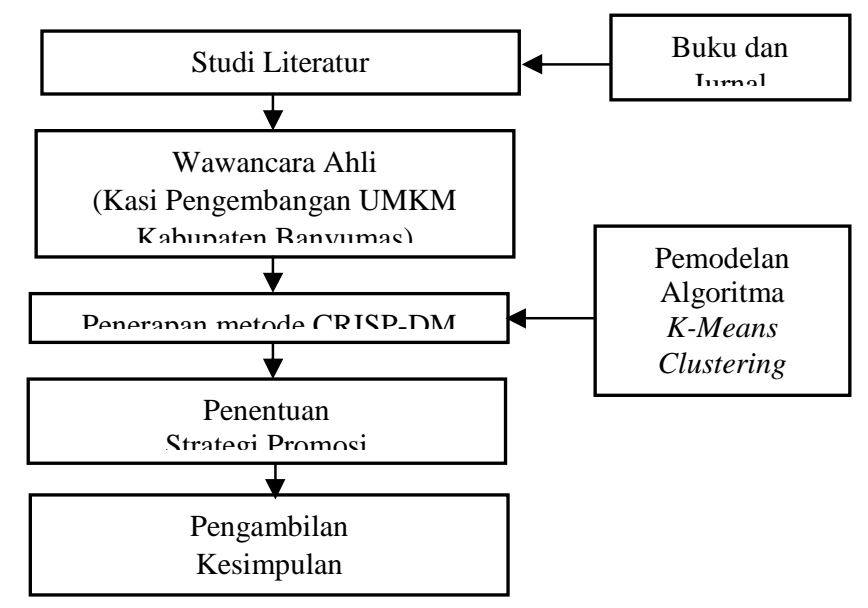

Gambar 1.1 Tahapan Penelitian

a. Studi Literatur

Tahapan awal yang dilakukan dalam penelitian dengan melakukan studi literatur pada jurnal, buku, dan penelitian yang berkaitan dengan data mining. Penelitian terkait yang dijadikan rujukan utama penelitian ini yaitu penelitian Aulia Tegar Rahman, Wiranto dan Rini Anggrainingsih, penelitian Johan Oscar Ong, dan penelitian Elly Murningsih dan Sri Kiswati.

b. Wawancara Ahli

Wawancara ahli merupakan proses penggalian informasi mengenai UMKM dan kendalanya yang ditanyakan langsung kepada Kepala Seksi Pengembangan UMKM Kabupaten Banyumas.

c. Penerapan Metode CRISP-DM

Pada tahapan ini pendekatan yang digunakan menggunakan metode Cross Industry Standard for Data Mining (CRISP-DM). CRISP-DM merupakan metode yang menggunakan model proses pengembangan data yang banyak digunakan para ahli untuk memecahkan masalah. Proses penelitian ini mengacu pada enam tahap CRISP-DM yaitu pemahaman bisnis, pemahaman data, persiapan data, pemodelan, evaluasi dan penyebaran. 


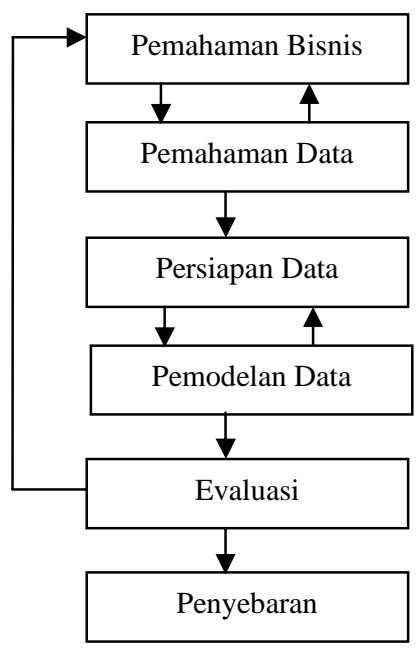

Gambar 1.2 Model CRISP-DM

(a) Pemahaman Bisnis

Pengolahan data UMKM di daerah Purwokerto Selatan yaitu karena terjadinya penurunan jumlah UMKM di Kelurahan Purwokerto Khususnya Purwokerto Selatan dengan jumlah 30 UMKM pada tahun 2016 hingga 2017 akibat kredit macet, dan memiliki kemampuan menghasilkan produk akan tetapi tidak bisa memasarkan produk dengan baik. Tujuan bisnis dari pengolahan data ini dapat dijadikan sebagai salah satu dasar pengambilan keputusan untuk menentukan jenis promosi yang tepat sasaran agar Dinas Tenaga Kerja, Koperasi dan Usaha Kecil dan Menengah Kabupaten Banyumas dapat membantu UMKM supaya tidak gulung tikar yang menyebabkan penurunan jumlah UMKM.

Strategi awal yang diterapkan adalah meminta data UMKM Purwokerto ke Dinas Tenaga Kerja, Koperasi dan Usaha Kecil dan Menengah Kabupaten Banyumas dengan cara melakukan pengajuan penelitian ke Direktorat Jenderal Kesatuan Bangsa (Kesbangpol) dan Politik Kementerian Dalam Negeri yang kemudian diteruskan ke Badan Penelitian dan Pengembangan Pertahanan Kementerian Pertahanan (Balitbang). Setelah itu, pengambilan data UMKM Purwokerto dilakukan di Dinas Tenaga Kerja, Koperasi dan Usaha Kecil dan Menengah Kabupaten Banyumas bagian UKM.

(b) Pemahaman Data

Pengumpulan data awal berupa dokumen excel dengan format .xlsx. Data UMKM dideskripsikan dengan nama, alamat, desa/kelurahan, klasifikasi, tenaga kerja, jenis usaha, lokasi usaha, omset, dan aset. Setelah data didapatkan, dilakukan eksplorasi data sejumlah 350 record data UMKM di sektor industri dan pengolahan. Namun demikian, ada beberapa yang kosong (null) pada variabel omset dan aset.

(c) Persiapan Data

Pada persiapan data dilakaukan preprocessing untuk menjaga kualitas data. Data cleaning dilakukan dengan menghapus missing value pada attribut yang memiliki banyak data yang kosong atau null agar data yang dihitung lebih akurat karena sudah tidak ada missing value. Pada tahap ini data cleaning dilakukan dengan menghapus missing value pada attribut aset dan omset yang dilakukan karena ada beberapa kolom yang kosong dibagian data tersebut. Setelah dilakukan seleksi, didapatkan data sebanyak 284 UMKM. Setelah dilakukan data reduction, jumlah dataset terbagi menjadi tiga kolom yaitu jenis usaha, omset, dan aset. Data yang sudah bersih, memasuki tahap transformasi data, data berjenis non nominal dilakukan proses inisialisasi kedalam bentuk angka/numerikal seperti Tabel 1.3. Aturan transformasi data ini didasarkan kepada jenis usaha yang memiliki frekuensi terbesar diberi inisial dengan angka 1 dan kedua diberi inisial angka 2, begitu seterusnya sepeti pada Tabel 1.2. 
Tabel 1.2 Kriteria Transformasi Data UMKM

\begin{tabular}{|l|c|c|}
\hline \multicolumn{1}{|c|}{ Jenis Usaha } & Frekuensi & Transformasi \\
\hline Kerajinan & 124 & 1 \\
\hline Kuliner & 123 & 2 \\
\hline Jasa & 28 & 3 \\
\hline Perdagangan & 9 & 4 \\
\hline
\end{tabular}

Tabel 1.3 Sample Hasil Transformasi Data UMKM

\begin{tabular}{|l|r|r|r|r|r|}
\hline \multicolumn{1}{|c|}{ Atribut } & \multicolumn{3}{c|}{ Dataset } \\
\hline Jenis Usaha & 2 & 4 & 1 & $\ldots$ & 1 \\
\hline Omset & 120000000 & 36000000 & 1000000 & $\ldots$ & 1340000000 \\
\hline Aset & 18000000 & 5400000 & 2000000 & $\ldots$ & 201000000 \\
\hline
\end{tabular}

(d) Pemodelan Data

Pada penelitian ini, gambaran pemrosesan data menggunakan algoritma K-Means. Berikut adalah langkah yang digunakan dalam pemodelan ini:

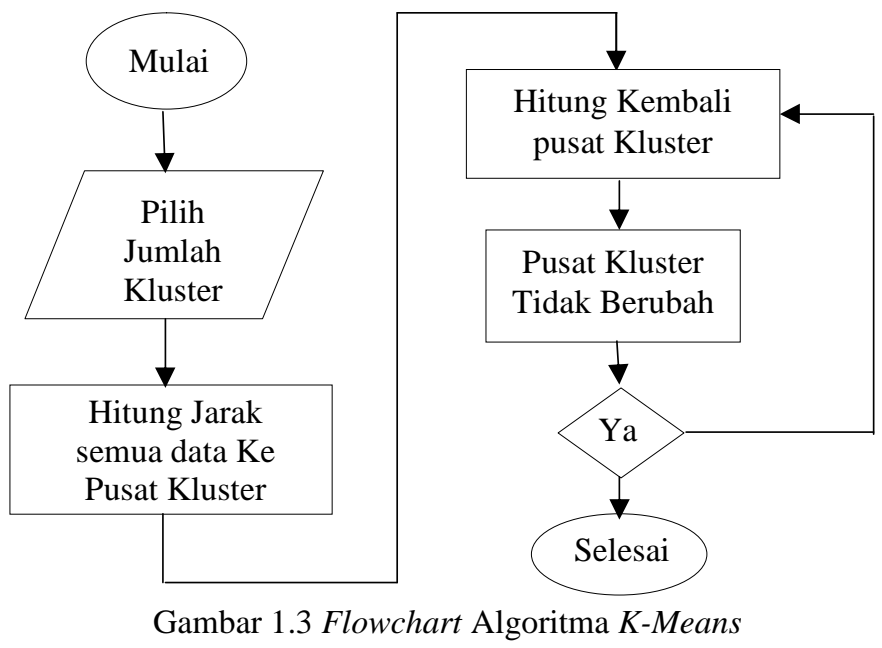

1. Jumlah cluster $(\mathrm{K})$ yang digunakan dalam penelitian ini adalah 3 cluster seperti pada tabel 1.4.

Tabel 1.4 Titik Pusat Awal Cluster

\begin{tabular}{|l|c|r|r|}
\hline \multicolumn{1}{|c|}{ Titik Pusat Awal } & Jenis Usaha & Omset & \multicolumn{1}{|c|}{ Aset } \\
\hline Cluster 1 & 2 & 48000000 & 7200000 \\
\hline Cluster 2 & 3 & 120000000 & 18000000 \\
\hline Cluster 3 & 1 & 465000000 & 69750000 \\
\hline
\end{tabular}

2. Hitung jarak setiap data ke pusat cluster dengan menggunakan persamaan Euclidean Distance. Berikut adalah persamaan yang digunakan dengan 3 atribut. Pada penelitian ini, jarak akan dihitung dari data UMKM pertama ke pusat cluster pertama dengan persamaan sebagai berikut:

$$
\begin{aligned}
& =\sqrt{(1)^{2}+(72000000)^{2}+(10800000)^{2}} \\
& =\sqrt{(2-1)^{2}+(120000000-48000000)^{2}+(18000000-7200000)^{2}} \\
& =72805494,3
\end{aligned}
$$

Dari hasil perhitungan jarak diatas, maka didapatkan hasil jarak antara data pertama dengan pusat cluster pertama adalah 72805494,3. Setelah itu menghitung jarak data pertama dengan pusat cluster kedua sebagai berikut: 
$\mathrm{d}(1,2)$

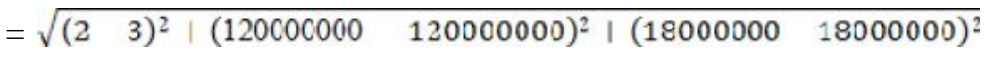

$$
\begin{aligned}
& =\sqrt{ }(-1)^{2}+(0)^{2}+(0)^{2} \\
& =1
\end{aligned}
$$

Dari perhitungan jarak diatas, didapatkan hasil data pertama dengan pusat cluster kedua adalah 1. Kemudian hitung jarak data pertama dengan pusat cluster pertama dengan persamaan:

$$
\begin{aligned}
& =\sqrt{(2-2)^{2}+(120000000-465000000)^{2}+(18000000-69750000)^{2}} \\
& =\sqrt{0+(-345000000)^{2}+(-51750000)^{2}} \\
& =345032038,6
\end{aligned}
$$

Dari perhitungan tersebut didapatkan bahwa hasil jarak data pertama ke cluster ketiga adalah

\begin{tabular}{|c|c|c|c|c|c|}
\hline \multirow{3}{*}{ No } & \multicolumn{5}{|c|}{ Iterasi-1 } \\
\hline & \multicolumn{3}{|c|}{ Jarak Ke } & \multicolumn{2}{|c|}{ Jarak Terdekat } \\
\hline & C1 & $\mathrm{C} 2$ & C3 & Jarak & Kelas \\
\hline 1 & 72805494,3 & 1 & 345032038,6 & 1 & 2 \\
\hline 2 & 27302060,36 & 45503433,94 & 391332695,4 & 27302060,36 & 1 \\
\hline 3 & 13298120,17 & 85375640,55 & 431304432 & 13298120,17 & 1 \\
\hline 4 & 43518846,49 & 116323901,2 & 462007165,7 & 43518846,49 & 1 \\
\hline 5 & 43518846,49 & 116323901,2 & 460047173,6 & 43518846,49 & 1 \\
\hline 6 & 43518846,49 & 116323901,2 & 540926992,8 & 43518846,49 & 1 \\
\hline 7 & 7088018,059 & 72178667,21 & 416254734 & 7088018,059 & 1 \\
\hline 8 & 702116685,5 & 630003174,6 & 285108523,3 & 285108523,3 & 3 \\
\hline 9 & 102023722,7 & 32695565,45 & 315228030 & 32695565,45 & 2 \\
\hline 10 & 60671245,25 & 12134249,05 & 357965230,4 & 12134249,05 & 2 \\
\hline 11 & 16987948,67 & 55817545,63 & 400317410,5 & 16987948,67 & 1 \\
\hline 12 & 42469871,67 & 115275366 & 459373266,3 & 42469871,67 & 1 \\
\hline 13 & 53390695,82 & 19414798,48 & 364314884,4 & 19414798,48 & 2 \\
\hline 14 & 53390695,82 & 19414798,48 & 364912946,5 & 19414798,48 & 2 \\
\hline 15 & 24268498,1 & 48536996,2 & 393002264,9 & 24268498,1 & 1 \\
\hline 16 & 37919528,28 & 110725022,6 & 455487314,3 & 37919528,28 & 1 \\
\hline 17 & 12134249,05 & 84939743,35 & 429724080,4 & 12134249,05 & 1 \\
\hline 18 & 31549047,53 & 41256446,77 & 386398013,8 & 31549047,53 & 1 \\
\hline 19 & 42469871,67 & 30335622,62 & 375377727,3 & 30335622,62 & 2 \\
\hline 20 & 33369184,89 & 106174679,2 & 450696800,2 & 33369184,89 & 1 \\
\hline 21 & 42469871,67 & 30335622,62 & 375018156,2 & 30335622,62 & 2 \\
\hline 22 & 27302060,36 & 45503433,94 & 390517453,9 & 27302060,36 & 1 \\
\hline
\end{tabular}
345032038,6. Berdasarkan hasil ketiga perhitungan diatas, dapat diambil kesimpulan bahwa jarak data ke cluster 2 merupakan jarak yang paling dekat. Hasil perhitungan manual masing-masing data dengan tiga atribut tersebut pada iterasi pertama dapat dilihat pada Tabel 1.5.

Tabel 1.5 Contoh Hasil Iterasi Pertama Menggunakan Euclidean Distance 


\begin{tabular}{|c|c|c|c|c|c|}
\hline \multirow{2}{*}{ No } & \multicolumn{5}{|c|}{ Iterasi-1 } \\
\cline { 2 - 6 } & $\mathbf{C 1}$ & C2 & C3 & Jarak Ke & Kelas \\
\cline { 2 - 6 } & 17190186,15 & 55615308,14 & 400089272,2 & 17190186,15 & 1 \\
\hline 23 & 31346810,05 & 104152304,3 & 460172496,7 & 31346810,05 & 1 \\
\hline 24 & 54604120,72 & 18201373,57 & 363311257,7 & 18201373,57 & 2 \\
\hline 25 & &
\end{tabular}

3. Setelah semua data dimasukkan kedalam kelas yang sama berdasarkan cluster terdekat, lalu hitung kembali pusat cluster untuk menentukan iterasi kedua berdasarkan rata-rata anggota yang ada didalam cluster tersebut.

Perhitungan Centroid baru di Cluster 1,

$$
\begin{aligned}
\mathrm{x} & =\frac{27302060,36+13298120,17+43518846,49+\ldots+4000000}{153} \\
& =1,790849673 \\
\mathrm{y} & =\frac{45503433,94+85375640,55+116323901,2+\ldots+15728954,19}{153} \\
& =39786411,76 \\
\mathrm{z} & =\frac{391332695,4+4313044332+462007165,7+\ldots+401619919,8}{153} \\
& =6989637,255
\end{aligned}
$$

Perhitungan Centroid baru di Cluster 2,

$$
\begin{aligned}
\mathrm{x} & =\frac{72805494,3+102023722,7+60671245,25+\ldots+110521898,3}{13} \\
& =1,767123288 \\
\mathrm{y} & =\frac{1+32695565,45+12134249,05+\ldots+40635575,55}{73} \\
& =148580821,9 \\
\mathrm{z} & =\frac{345032038,6+315228030+357965230,4+\ldots+306540780,3}{73} \\
& =24113424,66
\end{aligned}
$$

Perhitungan Centroid baru di Cluster 3,

$$
\begin{aligned}
\mathrm{x} & =\frac{702116685,5+272009416,2+583455141,8+\ldots+336000059,5}{58} \\
& =1,5 \\
\mathrm{y} & =\frac{630003174,6+199203921,9+510649647,5+\ldots+264229067,3}{58} \\
& =485881034,5 \\
\mathrm{z} & =\frac{285108523,3+148123317+161227414,8+\ldots+83967277,88}{58} \\
& =73575862,07
\end{aligned}
$$

Sehingga didapatkan centroid baru dari cluster 1, 2 dan 3 dapat seperti pada tabel 1.6. 
Tabel 1.6 Centroid baru dari perhitungan rata-rata iterasi 1

\begin{tabular}{|c|r|c|c|}
\hline Centroid & \multicolumn{1}{|c|}{$\mathbf{X}$} & $\mathbf{Y}$ & $\mathbf{Z}$ \\
\hline $\mathbf{1}$ & 1,790849673 & 39786411,76 & 6989637,255 \\
\hline $\mathbf{2}$ & 1,767123288 & 148580821,9 & 24113424,66 \\
\hline $\mathbf{3}$ & 1,5 & 485881034,5 & 73575862,07 \\
\hline
\end{tabular}

4. Setelah centroid baru dari setiap cluster didapatkan, lakukan iterasi kembali hingga setiap cluster tidak berubah lagi dengan melihat tidak ada lagi data yang berpindah dari cluster satu ke cluster yang lainnya.

Tabel 1.7 Centroid baru dari perhitungan rata-rata iterasi 2

\begin{tabular}{|c|c|c|c|}
\hline Centroid & $\mathbf{X}$ & $\mathbf{Y}$ & $\mathbf{Z}$ \\
\hline $\mathbf{1}$ & 1,779141104 & 42864546,01 & 7309536,81 \\
\hline $\mathbf{2}$ & 1,818181818 & 164860606,1 & 30050606,06 \\
\hline $\mathbf{3}$ & 1,454545455 & 495401818,2 & 71314545,45 \\
\hline
\end{tabular}

Tabel 1.8 Centroid baru dari perhitungan rata-rata iterasi 3

\begin{tabular}{|c|c|c|c|}
\hline Centroid & $\mathbf{X}$ & $\mathbf{Y}$ & $\mathbf{Z}$ \\
\hline $\mathbf{1}$ & 1,76744186 & 45747215,12 & 7695898,256 \\
\hline $\mathbf{2}$ & 1,859649123 & 175424561,4 & 32475438,6 \\
\hline $\mathbf{3}$ & 1,454545455 & 495401818,2 & 71314545,45 \\
\hline
\end{tabular}

Tabel 1.9 Centroid baru dari perhitungan rata-rata iterasi 4

\begin{tabular}{|c|c|c|c|}
\hline Centroid & $\mathbf{X}$ & $\mathbf{Y}$ & $\mathbf{Z}$ \\
\hline $\mathbf{1}$ & 1,764367816 & 46388626,44 & 8131577,586 \\
\hline $\mathbf{2}$ & 1,872727273 & 178110909,1 & 31998181,82 \\
\hline $\mathbf{3}$ & 1,454545455 & 495401818,2 & 71314545,45 \\
\hline
\end{tabular}

Tabel 1.10 Centroid baru dari perhitungan rata-rata iterasi 5

\begin{tabular}{|c|r|r|r|}
\hline Centroid & \multicolumn{1}{|c|}{$\mathbf{X}$} & \multicolumn{1}{c|}{$\mathbf{Y}$} & \multicolumn{1}{c|}{$\mathbf{Z}$} \\
\hline $\mathbf{1}$ & 1,762711864 & 47443056,5 & 8557596,045 \\
\hline $\mathbf{2}$ & 1,884615385 & 182121153,8 & 31925000 \\
\hline $\mathbf{3}$ & 1,454545455 & 495401818,2 & 71314545,45 \\
\hline
\end{tabular}

Tabel 1.11 Centroid baru dari perhitungan rata-rata iterasi 6

\begin{tabular}{|c|r|r|r|}
\hline Centroid & \multicolumn{1}{|c|}{$\mathbf{X}$} & \multicolumn{1}{c|}{$\mathbf{Y}$} & \multicolumn{1}{c|}{$\mathbf{Z}$} \\
\hline $\mathbf{1}$ & 1,75419 & 48197882,68 & 8654718 \\
\hline $\mathbf{2}$ & 1,92 & 184806000 & 32512000 \\
\hline $\mathbf{3}$ & 1,454545 & 495401818,2 & 71314545 \\
\hline
\end{tabular}

Tabel 1.12 Centroid baru dari perhitungan rata-rata iterasi 7

\begin{tabular}{|c|r|r|r|}
\hline Centroid & $\mathbf{X}$ & \multicolumn{1}{|c|}{$\mathbf{Y}$} & \multicolumn{1}{c|}{$\mathbf{Z}$} \\
\hline $\mathbf{1}$ & 1,756906 & 48812271 & 9573450 \\
\hline $\mathbf{2}$ & 1,916667 & 188181250 & 30041667 \\
\hline $\mathbf{3}$ & 1,454545 & 495401818,2 & 71314545 \\
\hline
\end{tabular}


Tabel 1.13 Centroid baru dari perhitungan rata-rata iterasi 8

\begin{tabular}{|c|c|c|c|}
\hline Centroid & $\mathbf{X}$ & $\mathbf{Y}$ & $\mathbf{Z}$ \\
\hline $\mathbf{1}$ & 1,758241758 & 49203412,09 & 9531837,912 \\
\hline $\mathbf{2}$ & 1,914893617 & 189631914,9 & 30638297,87 \\
\hline $\mathbf{3}$ & 1,454545455 & 495401818,2 & 71314545,45 \\
\hline
\end{tabular}

Tabel 1.14 Centroid baru dari perhitungan rata-rata iterasi 9

\begin{tabular}{|c|c|c|c|}
\hline Centroid & $\mathbf{X}$ & $\mathbf{Y}$ & $\mathbf{Z}$ \\
\hline $\mathbf{1}$ & 1,758241758 & 49203412,09 & 9531837,912 \\
\hline $\mathbf{2}$ & 1,914893617 & 189631914,9 & 30638297,87 \\
\hline $\mathbf{3}$ & 1,454545455 & 495401818,2 & 71314545,45 \\
\hline
\end{tabular}

5. Berdasarkan hasil perhitungan diatas, dapat dilihat jika titik centroid tidak berubah pada iterasi ke-9 (sembilan) artinya pemodelan data menggunakan K-Means selesai.

(e) Evaluasi

Pada tahap evaluasi ini lebih difokuskan pada model yang dihasilkan sudah sesuai standar K-Means Clustering dan tidak ada yang dilewatkan saat melakukan tahap awal hingga tahap pemodelan selesai. langkah selanjutnya yang diplih adalah memutuskan untuk melanjutkan ke tahap akhir.

\section{(f) Penyebaran}

Dalam tahap penyebaran pengetahuan atau informasi yang telah diperoleh akan diimplementasikan kedalam sebuah laporan dan dilakukan analisis dari masing-masing cluster yang didapat agar dapat dengan mudah dipahami oleh pihak yang memiliki kepentingan.

\section{d. Penentuan Strategi Promosi}

Penentuan strategi promosi ini didasarkan pada hasil wawancara yang didapat pada tahap wawancara ahli dan hasil studi literasi. Dimana, nantinya penulis akan memberikan rekomendasi strategi promosi berdasarkan cluster.

e. Pengambilan Kesimpulan

Tahap pengambilan kesimpulan ini merupakan tahap yang memiliki tujuan untuk mengambil intisari dari penulisan untuk dijadikan sebuah pemahaman yang utuh dan komperhensif. Berdasarkan kesimpulan yang diperoleh akan ditemukan alternatif solusi yang dapat ditawarkan untuk mengatasi permasalahan yang telah dirumuskan yaitu untuk menentukan strategi promosi bagi UMKM.

\section{RESULTS AND DISCUSSION}

Pada saat melakukan implementasi menggunakan sistem yang dibangun menggunakan bahasa pemrograman python. Hasil yang didapatkan yaitu pemrosesan data menggunakan $K$-Means berhenti pada iterasi ke-9 (sembilan) dengan hasil akhir jarak yang didapatkan sebesar 0 pada iterasi ke-9 (sembilan). Saat dilakukan pencocokan antara hitung manual dan menggunakan program, hasil yang didapatkan sama. Hal ini menunjukan tidak ada kesalahan saat membangun program. 


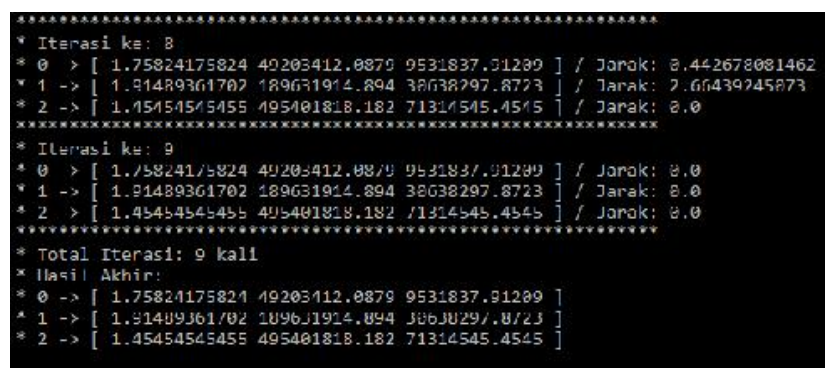

Gambar 1.1 Iterasi K-Means Menggunakan Python

kemudian akan dilakukan analisis dari cluster akhir yang didapatkan berdasarkan kedekatan jarak antara titik pusat (centroid) dengan data UMKM yang memiliki tiga atribut.

Tabel 1.15 Hasil Analisis Cluster 1

\begin{tabular}{|l|}
\hline \multicolumn{1}{|c|}{ Hasil Cluster Satu } \\
\hline Cluster satu terdiri dari 182 UMKM yang memiliki jenis usaha \\
\hline Kerajinan : 61 UMKM \\
\hline Kuliner : 105 UMKM \\
\hline Jasa: 15 UMKM \\
\hline Perdagangan: 1 UMKM \\
\hline Dengan rata-rata aset sebesar Rp 49.203.412 dan rata-rata omset sebesar Rp 9.531 .838 \\
\hline
\end{tabular}

Tabel 1.16 Hasil Analisis Cluster 2

\begin{tabular}{|l|}
\hline \multicolumn{2}{|c|}{ Hasil Cluster Dua } \\
\hline Cluster satu terdiri dari 47 UMKM yang memiliki jenis usaha \\
\hline Kerajinan : 23 UMKM \\
\hline Kuliner : 12 UMKM \\
\hline Jasa: 5 UMKM \\
\hline Perdagangan: 7 UMKM \\
\hline $\begin{array}{l}\text { Dengan rata-rata aset sebesar Rp 189.631.915 dan rata-rata omset sebesar Rp } \\
\text { 30.638.298 }\end{array}$ \\
\hline
\end{tabular}

Tabel 1.17 Hasil Analisis Cluster 3

\begin{tabular}{|l|}
\hline \multicolumn{2}{|c|}{ Hasil Cluster Tiga } \\
\hline Cluster satu terdiri dari 55 UMKM yang memiliki jenis usaha \\
\hline Kerajinan : 40 UMKM \\
\hline Kuliner : 6 UMKM \\
\hline Jasa: 8 UMKM \\
\hline Perdagangan: 1 UMKM \\
\hline $\begin{array}{l}\text { Dengan rata-rata aset sebesar Rp 495.401.818 dan rata-rata omset sebesar Rp } \\
71.314 .545\end{array}$ \\
\hline
\end{tabular}

Dari tabel diatas dapat dilihat bahwa cluster satu memiliki rata-rata aset dan omset sebesar Rp 49.203.412 dan Rp 9.531.838, didominasi oleh jenis usaha kuliner dan kerajinan. Kemudian cluster dua memiliki rata-rata aset sebesar Rp 189.631.915 dan rata-rata omset sebesar $\mathrm{Rp}$ 30.638.298. Sedangkan cluster tiga memiliki rata-rata aset sebesar $\mathrm{Rp}$ 495.401.818 dan rata-rata omset sebesar Rp 71.314.545. Sehingga dapat disimpulkan 
bahwa cluster 1 merupakan cluster yang harus diperhatikan karena memiliki rata-rata aset dan omset yang cukup rendah dibanding dua cluster lainnya.

Dari hasil analisis diatas, didapatkan persebaran data dalam bentuk ploting 3 (tiga) dimensi dengan nilai xyz dimana $\mathrm{x}$ merupakan jenis usaha, y merupakan omset dan $\mathrm{z}$ adalah aset pada sistem yang dibangun menggunakan python. Persebaran data tersebut dapat dilihat pada Gambar 1.2.

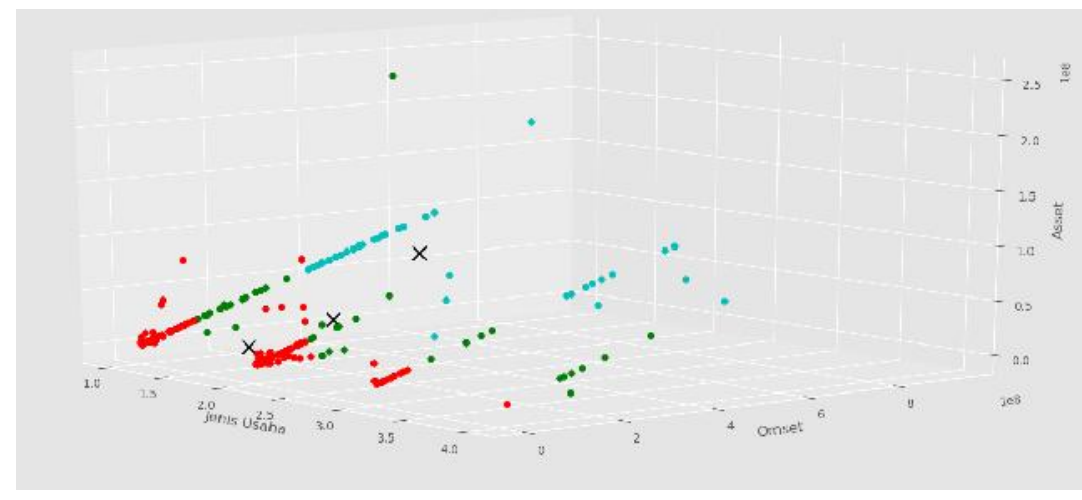

Gambar 1.2 Hasil Ploting 3D

Dari hasil ploting data tersebut dapat dilihat bahwa data pada cluster 1 (satu) merupakan data yang paling banyak muncul. Data dengan cluster 1 didefinisikan sebagai data dengan centroid yang dipilih berdasarkan omset usaha yang kecil. Artinya, sebagian besar UMKM yang diteliti memiliki omset usaha dengan rata-rata omset yang kecil.

Berdasarkan data hasil clustering yang telah diolah, maka dapat ditentukan beberapa strategi promosi yang dapat dilakukan oleh Dinas Tenaga Kerja, Koperasi dan Usaha Kecil dan Menengah Kabupaten Banyumas pada umumnya dan UMKM pada khususnya. Penentuan strategi promosi ini didasarkan pada dua aspek yaitu hasil proses wawancara dan hasil studi literasi. Dimana jika dikaitkan dengan hasil wawancara, maka strategi promosi yang didapat yaitu sebagai berikut:

Tabel 1.18 Strategi Promosi berdasarkan hasil wawancara

\begin{tabular}{|l|l|c|c|c|}
\hline No. & \multicolumn{1}{|c|}{ Strategi } & $\begin{array}{c}\text { Cluster } \\
\text { Satu }\end{array}$ & $\begin{array}{c}\text { Cluster } \\
\text { Dua }\end{array}$ & $\begin{array}{c}\text { Cluster } \\
\text { Tiga }\end{array}$ \\
\hline 1. & Mengikuti kegiatan temu usaha UMKM & $\sqrt{ }$ & $\sqrt{ }$ & $\sqrt{ }$ \\
\hline 2. & Mengikuti pameran UMKM & $\sqrt{ }$ & $\sqrt{ }$ & \\
\hline 3. & Bergabung dengan pojok UMKM & $\sqrt{ }$ & & \\
\hline 4. & $\begin{array}{l}\text { Memanfaatkan dunia digital sebagai upaya } \\
\text { pengembangan usaha }\end{array}$ & $\sqrt{ }$ & $\sqrt{ }$ & $\sqrt{ }$ \\
\hline
\end{tabular}

Dikarenakan adanya masalah penurunan jumlah UMKM akibat kredit macet dan ada UMKM memiliki kemampuan menghasilkan produk akan tetapi tidak bisa memasarkan produk dengan baik sehingga tidak bisa mengembangkan usaha serta memiliki kemungkinan kredit macet maka penelitian ini difokuskan pada cluster satu mengingat jumlah UMKM yang tinggi, omset dan aset paling rendah diantara tiga cluster yaitu rata-rata aset sebesar Rp 49.203.412 dan rata-rata omset sebesar Rp 9.531.838. Maka dilakukan strategi promosi dengan mengikuti kegiatan temu usaha UMKM dalam sebuah asosiasi atau komunitas yang sudah disediakan pemerintah. Mengikuti pameran UMKM dengan membuat produk yang unik dan memiliki daya saing khususnya bagi UMKM dengan jenis usaha kuliner serta kerajinan. Bagi UMKM dengan jenis usaha kuliner, dapat bergabung dengan pojok UMKM yang telah disediakan pemerintah. Lalu, UMKM pada cluster ini dapat memanfaatkan dunia digital sebagai upaya pengembangan usaha dengan melakukan promosi dan penjualan online.

Lalu untuk UMKM pada cluster dua dengan rata-rata jumlah aset sebesar Rp 189.631.915 dan rata-rata omset sebesar Rp 30.638.298 adalah dengan mengikuti kegiatan temu usaha UMKM untuk memperkenalkan produk dan menambah wawasan usaha, mengikuti pameran UMKM serta memanfaatkan dunia digital sebagai upaya pengembangan usaha melalui promosi dan penjualan online. 
Berdasarkan hasil clustering pada cluster ketiga dengan rata-rata aset dan omset paling besar yaitu $\mathrm{Rp}$ 495.401.818 dan Rp 71.314.545, disarankan melakukan strategi dengan cara mengikuti temu usaha dan memanfaatkan dunia digital sebagai upaya pengembangan usaha melalui promosi dan penjualan online. Kemudian akan dilakukan analisis strategi berdasarkan promotion mix pada setiap cluster yang terbentuk. Hal ini diharapkan dapat sesuai dengan tujuan bisnis yang telah dijelaskan diawal proses CRISP-DM.

Tabel 1.19 Strategi Promosi Berdasarkan Promotion Mix

\begin{tabular}{|l|l|c|c|c|}
\hline No. & \multicolumn{1}{|c|}{ Strategi Promosi } & $\begin{array}{c}\text { Cluster } \\
\text { Satu }\end{array}$ & $\begin{array}{c}\text { Cluster } \\
\text { Dua }\end{array}$ & $\begin{array}{c}\text { Cluster } \\
\text { Tiga }\end{array}$ \\
\hline 1. & Periklanan & & $\sqrt{ }$ & $\sqrt{ }$ \\
\hline 2. & Penjualan Personal & $\sqrt{ }$ & $\sqrt{ }$ & $\sqrt{ }$ \\
\hline 3. & Promosi Penjualan & $\sqrt{ }$ & $\sqrt{ }$ & $\sqrt{ }$ \\
\hline 4. & Hubungan Masyarakat & $\sqrt{ }$ & $\sqrt{ }$ & $\sqrt{ }$ \\
\hline 5. & Pemasaran Langsung & $\sqrt{ }$ & $\sqrt{ }$ & $\sqrt{ }$ \\
\hline
\end{tabular}

Strategi promosi bagi UMKM berdasarkan hasil clustering untuk setiap cluster yang terbentuk adalah dengan melakukan penyelarasan menggunakan promotion mix berdasarkan rata-rata omset dari masingmasing cluster. Dimana pada cluster 1 (satu) dengan rata-rata omset sebesar Rp 9.531.838 memungkinkan UMKM pada cluster 1 (satu) melakukan penjualan personal, promosi penjualan, hubungan masyarakat, dan pemasaran langsung. Sedangkan pada cluster 2 (dua) dan cluster 3 (tiga) dilakukan semua kegiatan promotion mix.

\section{KESIMPULAN}

1. Strategi promosi berdasarkan wawancara langsung difokuskan pada cluster pertama dengan menyelaraskan tiga aspek yaitu jenis usaha, omset dan aset. Kemudian didapatkan empat strategi promosi yaitu mengikuti kegiatan temu usaha UMKM dalam sebuah asosiasi atau komunitas yang sudah disediakan pemerintah. Mengikuti pameran UMKM dengan membuat produk yang unik dan memiliki daya saing khususnya bagi UMKM dengan jenis usaha kuliner serta kerajinan. Bagi UMKM dengan jenis usaha kuliner, dapat bergabung dengan pojok UMKM yang telah disediakan pemerintah. Lalu, UMKM pada cluster ini dapat memanfaatkan dunia digital sebagai upaya pengembangan usaha dengan melakukan promosi dan penjualan online.

2. Strategi promosi bagi UMKM berdasarkan hasil clustering untuk setiap cluster yang terbentuk adalah dengan melakukan penyelarasan menggunakan promotion mix berdasarkan rata-rata omset dari masingmasing cluster.

\section{ACKNOWLEDGMENT}

Terimakasih kepada Dinas Tenaga Kerja, Koperasi dan Usaha Kecil dan Menengah Kabupaten Banyumas atas ijin pelaksanaan penelitian. Terimakasih kepada Kepala Seksi Pengembangan UMKM Banyumas atas waktu yang diberikan dalam pelaksanaan wawancara. Terimakasih kepada Bapak Ade Rahmat Iskandar S. Kom., M.T. dan Ibu Atik Febrianti, S.T., M.T atas bimbingannya.

\section{REFERENCES}

[1] L. P. P. I. (LPII) Bank Indonesia, Profil Bisnis Usaha Mikro, Kecil dan Menengah (UMKM). 2015.

[2] B. P. S. (BPS), "Pertumbuhan Jumlah Usaha Mikro, Kecil dan Menengah (UMKM) Nasional.” p. 1, 2016.

[3] S. K. P. Selatan, "Data Usaha Mikro, Kecil dan Menengah (UMKM) Purwokerto Selatan.” 2018.

[4] J. Han, M. Kamber, and J. Pei, Data Mining: Concepts and Techniques. 2012.

[5] P.-N. Tan, M. Steinbach, and V. Kumar, "Cluster Analysis: Basic Concepts and Algorithms," Introd. to Data Min., p. Chapter $8,2005$.

[6] A. T. Rahman, "Coal Trade Data Clustering Using K-Means (Case Study Pt. Global Bangkit Utama)," ITSMART J. Teknol. dan Inf., vol. 6, no. 1, pp. 24-31, 2017.

[7] J. O. Ong, "Implementasi Algoritma K-Means Clustering Untuk Menentukan Strategi Marketing President University,” J. Ilm. Tek. Ind., vol. 12, no. April, pp. 10-20, 2013.

[8] E. Muningsih and S. Kiswati, "Penerapan Metode K-Means Untuk Clustering Produk Online Shop Dalam Penentuan Stok Barang," J. Bianglala Inform., vol. 3, no. 1, p. 8, 2015

[9] A. P. Fadillah, "Penerapan Metode CRISP-DM untuk Prediksi Kelulusan Studi Mahasiswa Menempuh Mata Kuliah (Studi Kasus Universitas XYZ)," J. Tek. Inform. dan Sist. Inf., vol. 1, no. 3, pp. 260-269, 2015.

[10] B. E. Adiana, I. Soesanti, A. E. Permanasari, J. G. No, J. G. No, and J. G. No, “Analisis Segmentasi Pelanggan Menggunakan Kombinasi RFM Model dan Teknik Clustering," no. 2, pp. 23-32, 2018. 